\title{
Urban sustainability challenges : Democracy and spatial injustices in ModernTunisia
}

\author{
Abdesselem MAHMOUD \\ Associate Professor of Urban Sociology \\ National School of Architecture and Town Planning, Carthage University, Tunis-Tunisia \\ Al-Quds Street, Sidi Bou Saïd, 2026, Tunis-Tunisia \\ abdesselemahmoud@yahoo.fr
}

\begin{abstract}
In this paper, the author addresses spatial injustices in Tunisia, and seeks to which extent social and territorial inequalities could hamper democracy. Many urban disparities and social anomies such as informal sector, terrorism, unemployment, and usustainable development process threaten the vulnerable democracy transition in Tunisia.

The author described and analyzed urban planning process since independency to noawadays. He analyzed the successive economic development policy makings undertook by a mono-party Nation-State. The top down development policies implemented until nowadays entailed a big gap between coastal areas and inland. The former benefitted of its site across the sea shores and proximity to Tunis and former regime. Many factors fostered export industries and tourism activities. The latters were left behind due to their lack of resources and urban planning policy dominated by neo liberal capitalist development in favor of Tunis urban primacy and the littoral where concentrated most foreign and local investments.

Urban disparities and inequalities in Tunisia join in a networked society where local and global actors play a key role in economic, social, and urban development process in Tunisia. Tunisian society is a subsystem within a global system (Wallerstein, 2012), and what is happening is not conjonctural, but it is due to global social movements (Sassen 2007 ; Castells 2012 ; Braudel, 1992 ; Amin, 2003). Terrorism, pollution,and inequalities are not per se, but are the negative results of a a myriad of factors : economic, politics, cultural, emotional, aesthetics, social and urban morphologies. Many economic, social, and political actors intervened and interconnected in public and private arenas and triggered those anomies.

Fair urban policies are expected to be achieved through a multilevel governance in order to implement the revolution objectives in Tunisia. Otherwise, a representative democracy only, won't fulfil the well-being expected by large Tunisian people. Sustainable urban governance requires a multi-scalar bottom-up and top-down policymaking. In Tunisia, after democratic transition success, the state should be revamped, and compensate its deficit. A sustainable urban planning implies a holistic policy framework involving private and public sectors, and civil society actors locally, regionally, and globally.
\end{abstract}

Key Words : Challenges /Democracy/ Injustices /Space/ Sustainable /Tunisia/ Urban

\section{Council for Innovative Research}

Peer Review Research Publishing System

Journal: Journal of Social Sciences Research

Vol .7, No.2

jssreditor.cir@gmail.com

www.jssronline.com

1281 | P a g e

April 20,2014 


\section{INTRODUCTION}

After the successful elections (October, 26, 2014) Tunisia will be faced with a dilemma : how democratic process transition undertook by the quartet (UGTT, UTICA, OAT, and LTDH) 1 and civil society actors could be twinned with a sustainable urban development ? However, many factors (e.g., Terrorism, inequalities, and corruption), could undermine democratic process if we share some scholars theses that "inequalities undermine democracy » (Fraser 2007, Fainstain 2010, to cite but a few). The urban gap and social inequalities dating back to preindependencyperiod, are remarkably deepening despite the Nation-state successive efforts to implement social and urban development. Nevertheless, the development policies were-and continue to bemadein the mainstream of a global liberal capitalism. The Nation-State weakened in the aftermath of December, 17th, 2010s and January, 14th, 2011 revolution. Youth unemployment had hugely grown, mainly amongst university graduates. Most of the populations living in the inland, and vulnerable social groups(i.e., women, poors, lower middle classes)become more and more excluded, impoverished. Moreover, terrorism acts occured against security, military, opposition leaders. As a network of networks, this phenomenon is staggering in Tunisia in the urban vacuum, chaotic spaces(i.e., Chaambi2, desertic areas, popular quarters where it finds home and endorsement). The urban syndrome in Tunisia is the grassroots of this phenomenon. Our problematic is focusing on the urban hiatus as resilient to a democratic process. Elections are not sufficient to garantee a steady democracy in Tunisia. How economic well-being could be achieved to sustain the ongoing democratic process in Tunisia, and vice versa ? In order to address this key question, we emit the following hyopothesese :

Urban disparities and inequalities in Tunisia join in a networked society where local and global actors play a key role in economic, social, and urban development process. Tunisian society is a subsystem within a global system(Wallerstein, 2012), and what is happening is not conjonctural, but is due to global social movements(Sassen2007),(Castells, 2012), (Braudel 1992),(Amin, 2003).Terrorism, pollution, inequalities are not per se, but are due to a plurality of factors : economic, politics, cultural, emotional, aesthetics, social and urban morphologies. Myriad of actors interfere in public and private arenas and trigger those anomies.

Fair urban policies are expected to be achieved through a multilevel governance, in order to implement revolution objectives in Tunisia. Otherwise, a representative democracy only, wont fulfil the well-being expected by wide collapsed middle class and left behind people.

Our method is theoritical based on previous findings on the topic and theoritical and empirical studies led on the issue of Democracy and inequalities in Tunisia and elswhere. The system, networked society, actors, strategies, opportunities, and socio-cultural contexts are, in our opinion, worth for better understanding Tunisia social changes. The multilevel governance approach3(Corfee- Morlot ; Jan Lamia Kamal Chaoui ; Michael G. donovan ; Ian Cochran ; Alexis Robert and Pierre-Jonathan ; Teasdale 2009 ; Henrik Enderlein ; Sonja Walti ; Michael Zurn 2010s ; Gonzelman 2008 ; Marks 1993 ; Hughes 1996 to name but a few) allows, somehow,to explain, more accurately, new participative urban policies as a prerequisite for a sustainable urban development.

We will conclude by detecting the main social and urban anomies as problems of power relationships between rulers and ruled people which stem from a top down policy-makings followed by authoritarians regimes. A bottom-up policy making could be relevant enoughif twinned withinaccurate articulation and agencies within a multileval urban governance process.

\section{BISECTORIAL ECONOMY and BEYOND?}

Tunisian economy is still vulnerable due to its structural foundations. Inasmuch, Tunisia-as many other countriesis amongst a global network, the conception of two-tired economy is not relevant enough to understand economy syndrome in Tunisia.

Since independency, six econmic plans were implemented in order to garantee well-being to all Tunisians. Despite the efficiencies achieved, this objective haven't been reached. The first triennal plan along with liberal economic policieswhich since independency had been stressing on growth by saving and encouraging national private capital to contribute to the development effort deployed by the Nation-State. In fact, the first triennal economic plan focused on rural areas development by enhancing agriculture activities. In vain, rural development programs undertook by Tunisisian state failed to enhance agriculture sector.

During its first six economic development plans, Tunisia invested about the third of its GDP and saved the fifth of it which required a foreign indebtness to about 30 per cent of the investments amounts, the local saving financed more than third about 70 per cent. The primary colonial economy gave way to an enriched economic structures.

\footnotetext{
${ }^{1}$ Quartet is a consensual coalition formed of civil society organizations: Labor Trade Unions(UGTT), Trade Unions of Industry, Trade, and Crafts(UTICA), Tunisian Lawyers Order(OAT), and Tunisian Human Rights Ligue constituted to endorse technocratic government in order to implement the roadmap leading to democratic elections by the end of 2014.

${ }^{2}$ Chaambi is thhe highest mountains in Kasserine gouvernorate across Algerian borders where terrorists hide and act aigainst State agents and smugglers make arm and goods trafficking between Libya, Tunisia, and Algeria.

${ }^{3}$ Multi-level governance initially described a "system of continuous negotiationamonggovernments at several territorial tiers-supranational, national, regional and local” that was distinctive of EU structural policy (Marks 1993, Hooghe 1996)
} 
Textile and lether (22\%) and touristic industries emerged, 76 per cent, new resources developped oil (33per cent) workers revenues ( 9 per cent) and about 86 per cent in 1990s among which textile and lether 22 per cent, mechanics and electrics 6 per cent, tourism 15 per cent and workers 10 per cent.

In Tunisia, the so-called « socialist » experience led by Ahmad ben Salah in sixties was, in fact, a state capitalism because it was shaped and molded by a Nation-State policy dependent of capitalist core. The following economic and social policies during nineties until nowadays are dependent to Neo-Liberal capitalism, to the financial monetary capital logic. Hence, development process in Tunisia stems from local structures characterized by a deep gap between a hinterworld of an off-shore industrial activities and a hinterland (Dlala 2010s) underdevelopped and left behind by the successive governments who followed a top down policies.

The nation-State undertook many policy making in accordance with its near and foreign neighbourhood. Economic performances were achieved thanks to a wise enlightened politic leadership of Habib Bourguiba. Despite his lack of democracy, Bourguiba gained international trust which allowed economic development shaped by a set of development plans(e.g.,1st to 6th development plans). His reign from 1957 to 1986 was characterized by the implementation of six development plans (1961-1986). During the cooperativisation period the capitals fled to tourism where we favorited « capitalism » instead of « socialism ».

In 1973, the first Master urban planning plan was undertaken by Town Planning Direction (Group Eight) along with the new liberal economic policy led by Hedi Nouira (Prime Minister Deputy at that time) in the aftermath of the State Capitalism failure in 1969. The subsidies abolition decision triggered revolts all over Tunisia (January, 3d, 1984). Remark, the subsidy funds had been created by decree since French protectorate, June 281945 . It consisted to protect Tunisian households against cereal products highrising prices. Its objective by-passed the protection of households consumption power, it targeted also to garantee the minimum wages for agricultors in difficulties. Afterwards, the subsidy funds encompassed more food needs (i.e., milk, meat, energy)

The well-being has been conceived in terms of GDP growth only. Then, we wonder why Tunisian and egyptian economy growth were the best in the MENA and Africa though, uprisingsparkedinboth two countries. According to Joseph Stiglitz (Nobel Prize Economist), the well-being shouldn't be limited in GDP growth. It has also to take into consideration other dimensions (i.e., gender, health, education, governance). Otherwise, we still remain in the Kenysian and Fordist conceptions criticized in the sixties by many scholars as did Herbert Marcusein his book entitled : " the one-dimensional man »(1964) considering the new consumption society as more repressive and alienating the human being, and so did Eric Fromm in America in talking about « Revolution of Hope ». For Stiglitz, the well-being calculation must take into account the followings: "Material living standards (income, consumption and wealth), health, education, personal activities including work, political voice and governance, social connections and relationships, environment: present and future conditions, insecurity of an economics as well as physical nature. All these dimensions shape the people's well-being, and yet many of them are missed by conventional income measures (Stiglitz et al. 2009: 14-15)

In Tunisia, the new technocratic government had to say the truth that the budget lacks about 5.000billions TND. In sum, the government would be constrained to adopt an austerity measures like abolition or reduction of food and energy subsidies and has recourse to indebtness. Another difficult, but possible solution could be the revising of the taxation policy and fighting smugling and informal commerce. The inflation rate is reaching 5 per cent rate. The gap between region is deepening. Social uprising are growing. The Libyan authorities made a decision to close the Ras Jedir gate in the the southern borders between Tunisia and Libya wher many tunisian families live of smuggling activities since long times. The same events of outrage continue in the centre west (Sidi Bou Zid, Kasserine, Kairouan) and nearby Tunisian Algerian borders where many people earn their lives by informal commerce. Some unexpected factors (i.e., terrorism, former regime remnants, mentalities) withstand to the ongoing democratic transition process in Tunisia.

Until 2013, Transitional Governments adopted expansionary fiscal and monetary policies to spur growth and employment. Deficit was about of 6 per cent, government expending exceeded revenues.

Moreover, the increasing informal commerce through Tunisian Libyan and Algerian borders entailed high inflation rates reaching Inflation $5.6 \%$. The unemployment rate had also increased $18.9 \%$ comparing to the previous years. The first transitional governments increased public spending by increaing salaries and vouchsafing compensations to victims of former regime amongst General armnesty and reduced the level of taxation in order to attract and encourage local and foreign investorsors. Some private banks in difficulties were bailouted by government through central Bank. All these economic policy making didn't succeed to lift the Tunisian Economy.

\section{ENERGY, the BURNINGISSUE !}

The energy issue is in the core of the sustainable development. Tunisia had nearly achieved an energy sufficiency in the beginning of the third millenium. However, since 2005, a growing lack of energy ressources had been observed.

Tunisia has witnessed a decline in primary energy intensity by $27 \%$ with regard to 1990 s which reflectsagain in energetic productivity. This decline has clearly acceleratedfrom the year 2001, which urges us to wonder on the origin of this reduction. (Ben Hammamia et al. 2014 :) Industries, transports, and real estate consume the lion share of energy consumption in Tunisia. In fact, the energy intensity in the industrial sector hasdecreased by $28 \%$ in 2008 with regard to its level in 1990s since its ration of energy consumption has decreased. However,it 
increased by 18 per cent in the transport sector in 2008. Energetic sector in Tunisia is closely correlated to fossil energies consumptions. The atmospheric pollution of the neighborhood stems from those materials combustion. The higher is the economic growth, the lesser is household's well-being improvement.

The primary energy consumption had swiftly increased by 2013(7947Ktoe) 4 . Mehdi Abid et al. Highlighted : Given the dominance of industrial, transport and residential sectors in ultimate energy use, our descriptive as well as econometrical analyses will focus only on these three sectors. Moreover, we will consider that energy consumption depends only on the three basic components: oil, electricity, and natural gas because the other energy categories represent very small proportions and/or their consumption statistics are integrated in those of basic components. » (Abid and Maamer, $2012: 57$ )

However, well-being will not, henceforth, be measured only by economic growth. Healthcare, recreation, culture, freedom, security matter too much in the Human Development Index. As far as energy is concerned, it is in the core of Human development. In the growing information society, energy issue is very important. In a cybernetic approach of thinking, we find that the more we use information and knowledge in the daily life, the lesser we use physical energies(e.g., transportation means, household tasks, washing machines, electronic energies in day-today life activities). Moreover, the use of greenhouse gases in households, transportation, industries begot the overspread of the $\mathrm{CO} 2$ within ecosystem. It has negative impacts on human being. It damages health, entails natural risks (i.e., Ozone depletion).

Table 1 : Energy Resources in Tunisia

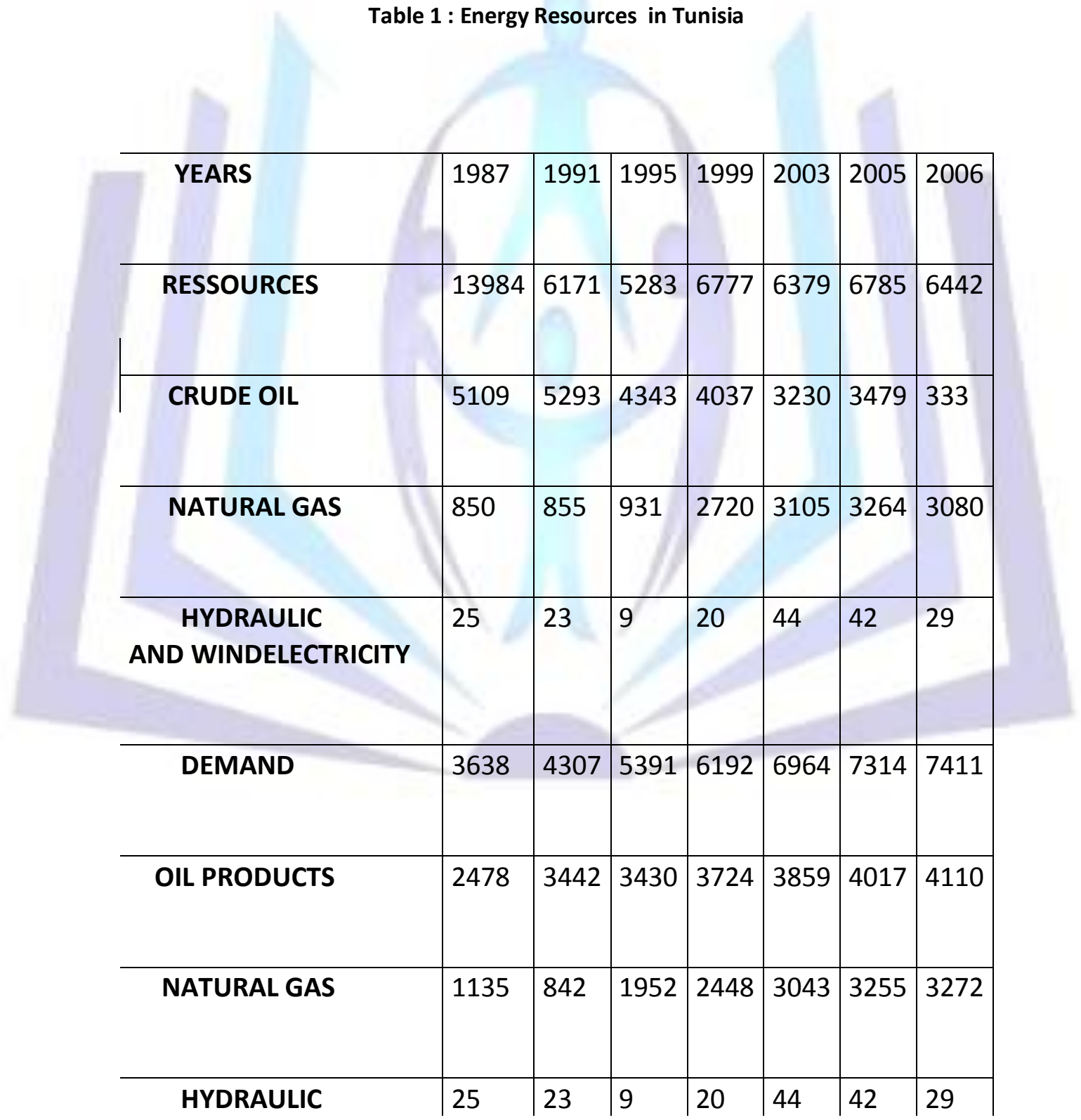

${ }^{4}$ Kilotonne of Oil Equivalent 


\begin{tabular}{c|c|c|c|c|c|c|c|} 
AND WINDELECTRICITY & & & & & & & \\
\hline COKE & & & & & & & \\
\hline
\end{tabular}

\section{Primary Energy Demand and Resouces evolution between 1987-2006(data in Ktep)}

Tunisia has many renewable energy resources. The report also argued that VLS-PVPS (Very Large Scale Photo Voltaic Power Systems) are not only technically and commercially feasible, but represent one of the most promising solar energy solutions. In desertic regions(Kebili, Tataouine) in the Southof Tunisia many sustainable energies opportunities such as natural gas extraction and solar plants could be implemented. Tunisian State will soon undertake an partnership within an institutional and research framework. Local inputs are importantly available, but energy good governance has been lacking.

\section{HOW to MEET the GROWINGE DEMAND of EERGY in TUNISIA?}

Due to population growth and increasing affluence, the total electricity consumption as well as the per capita consumption in Tunisia have increased over the last decade.

In the year 2010s, electricity sales, by STEG(Electric and Gas Tunisian Company) increased by 6.2 per cent from 12,254 GWh in 2009 to 13,015 GWh in 2010. Peaks occurred during summer afternoons because of air conditioning overuse, which threatens the electricity supply capacity. Some experts speculate that by 2016 , Tunisia will face severe shortages of electricity in the summer unless new power plants are constructed.

In addition, a cheap and stable supply of electricity is important to promote economic growth. After the revolution, cheap electricity plays an important role in jobs supplies.For example, STEG owns and operates nine wind farms in Tunisia. However, these turbines are not effectively used to their full potential because of their location wether faraway a suitable location where exists contantly wind supply, and more impotantly acroos urban settlement and hence disturb inhabitants of noises they cause.

As far as renewable energies are concerned in Tunisia, Hiroyuko Hito argued in this issue :

«The Tunisian government subsidies imported natural gas in order to make electricity costs low for end users. However, this puts financial pressure on the state's budget. The policy supports Algerian exporters and creates a dependency on these exports. Furthermore, electricity generated by other methods has to compete with subsidised gas prices. As a result, this provides a disincentive for installing one's own residential solar panels or investing in power plants. »(Hito,2013:19)

New energy extraction entailed contreversies about their obvious negative impacts on environment. Some shale gas gisements were discovered in Kairouan Center of Tunisia, but civil society and public opinion opposed to its extraction.

Shale gas is a new kind of resource which became available due to improvements in extraction technology. We drill deep into the ground vertically (e.g. from1,500 to $6,000 \mathrm{feets}) 5$ and drill horizontally(1000 to $3000 \mathrm{ft}$ ) by injecting cement in order to ovoid water leaking. Explosives are then fired into the well in order to allow shale gas extraction after removing water and sand due the fracturing. The plug in and the fracturing process is repeated in order to extract shale gas. However, because of potential environmental risks, some experts warn that drilling of shale gas introduces carcinogenic waste into the environment, and nearby water supplies. Therefore extraction of shale gas is banned in many countries, including but not limited to France, Germany, the United Kingdom, Argentina, South Africa, some parts of Australia, and the United States. Though in these latters, many deposits were drilled and supplied many job opportunities and replaced traditional energy resources (oil, coal).

Industrial, transport and residential sectors have the most share of energy consumption inTunisia. For example, in 2007, they represent about $83 \%$ of total energy consumption, while thetertiary and the agriculture sectors represent only $17 \%$. The figure below witnesses the evolution of energyconsumption by end-use sector in Tunisia from 1980s to 2007.

\section{Graphic 1 : Energy Resources in Tunisia}

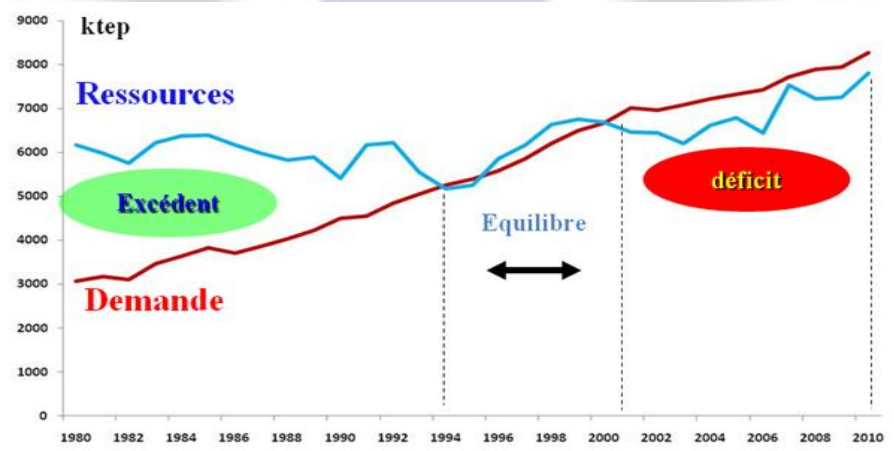

$53000 \mathrm{ft}=914.4 \mathrm{~m}$ 
Tunisian economy relies mainly on agriculture, tourism and exportation industries. Few energy resources exist. Oil production has been shrinking remarkably since 1980s. According US Energy Information Data (EIA) ${ }^{6}$, oil production decreased to 67,000 barrels per day in 2012. Moreover, Tunisia consumed the double of its natural gas production(3.7 cubic meters) in 2012 according the same source.Nawara gas field in Gabes region is expected to supply an additional volume of 353 million cubic feet (10 million cubic meters) of gas per day after it goes into operation in 2016. It is obvious that energy sector matters too much in economic and urban growth in Tunisia.

\section{THE URBAN GAP in TUNISIA:}

Urban planning documents: PAU (Urban Spatial Planning), SDAT(Master plan of town and country planning), CU(Urbanism Code), PRAT(Regional Master Plan of Urban Planning)...didn't fulfil urban policy makings objectives. However, the territorial inequalities deepened sharply widened in Tunisia.

The results of the parliamentary elections held on Sunday, October, 26, 2014 draws a political map where the Islamist party is still popular in the areas of its main hisoric areas origins, and inland of the country. The central and southern western governorates feel exluded by the modern nation-state. Nidaa Tunis had the lion shares of votes in northern areas of Tunisia. Eventhough, in the center West, it shares quite equally votes with Ennahdha.

Map1 : Political map in Tunisia, October, 2014

\section{Les élections tunisiennes}

Les partis en tête par circonscription

Nidaa Tounes Ennahdha
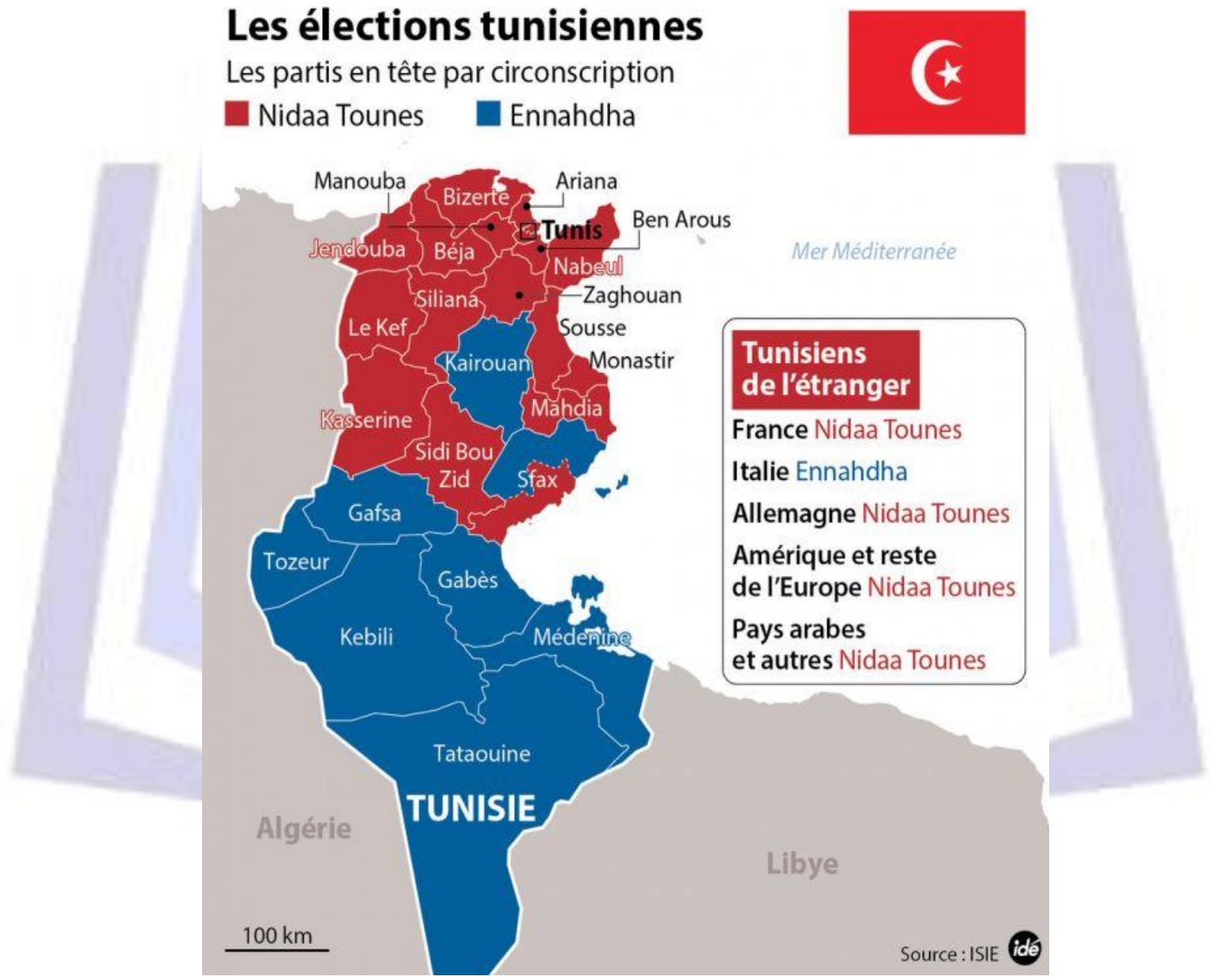

As seen on the maps, the secular party Nidaa Tounes has he most shares of votes in northern areas of Tunisia. It shares votes with Islamist party in central Eastern and Western areas of Tunisia. But, the southern governorates are mostly represented by Ennahdha party. Many reasons are behind those results. In the North, an awarness arised among voters that Ennahdha didn't fulfill its promises. In the South, many Ennahdha leaders are issued from there, and there is somehow, a compassion and sympathy towards this party alledgedly believed, «it fears God ». This sympathy to the Ennahdha could be explained also by some historic collective memory linked to the struggle against French protectorate, and the past political conflict between Habib Bourguiba and Salah Ben Youssef. Territorial inequalities play a key role in the present political map of Tunisia.

${ }^{6}$ International Energy Agency 
Graphic 2 : Parliamentary Elections Results in Tunisia, October, 2014

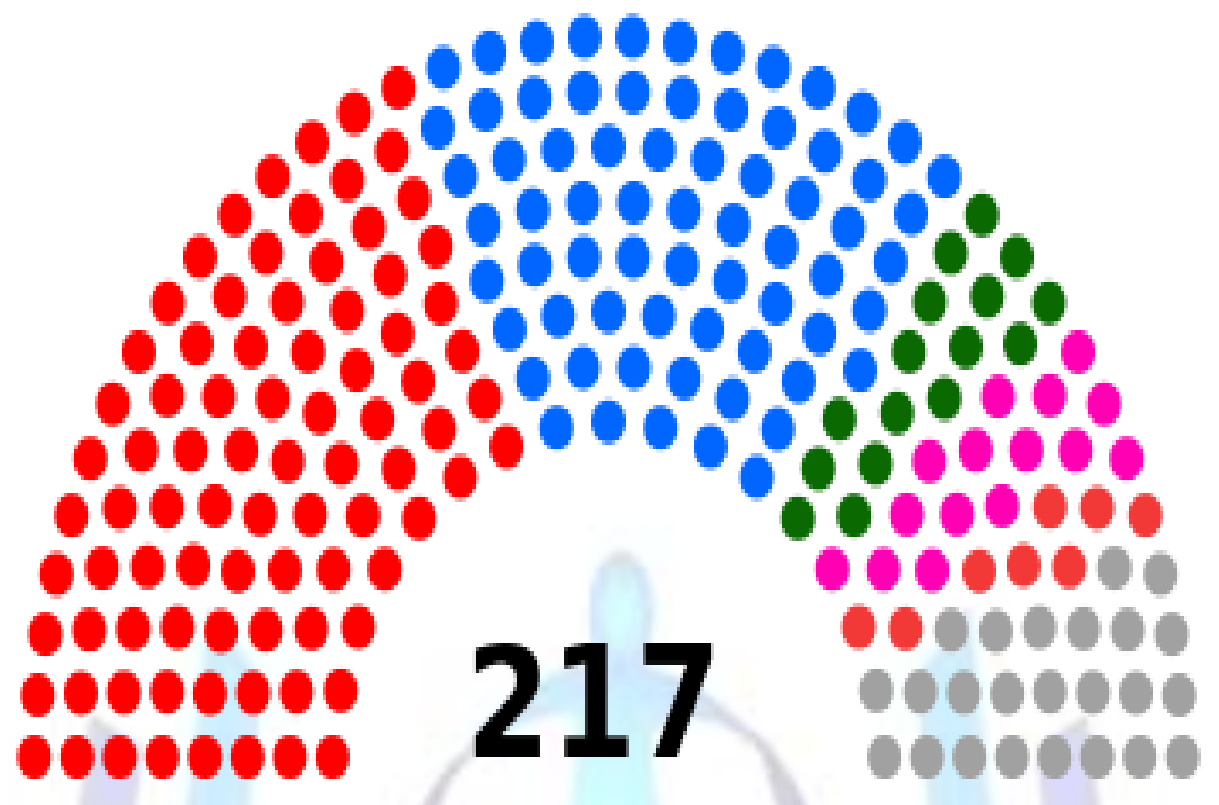

[Nidaa Tounes: 85 seats】 Ennahda Movement: 69 seats

[Popular Front: 15 seats】 Free Patriotic Union: 16 seats

[ Afek Tounes: 8 seats[Others: 24 seats

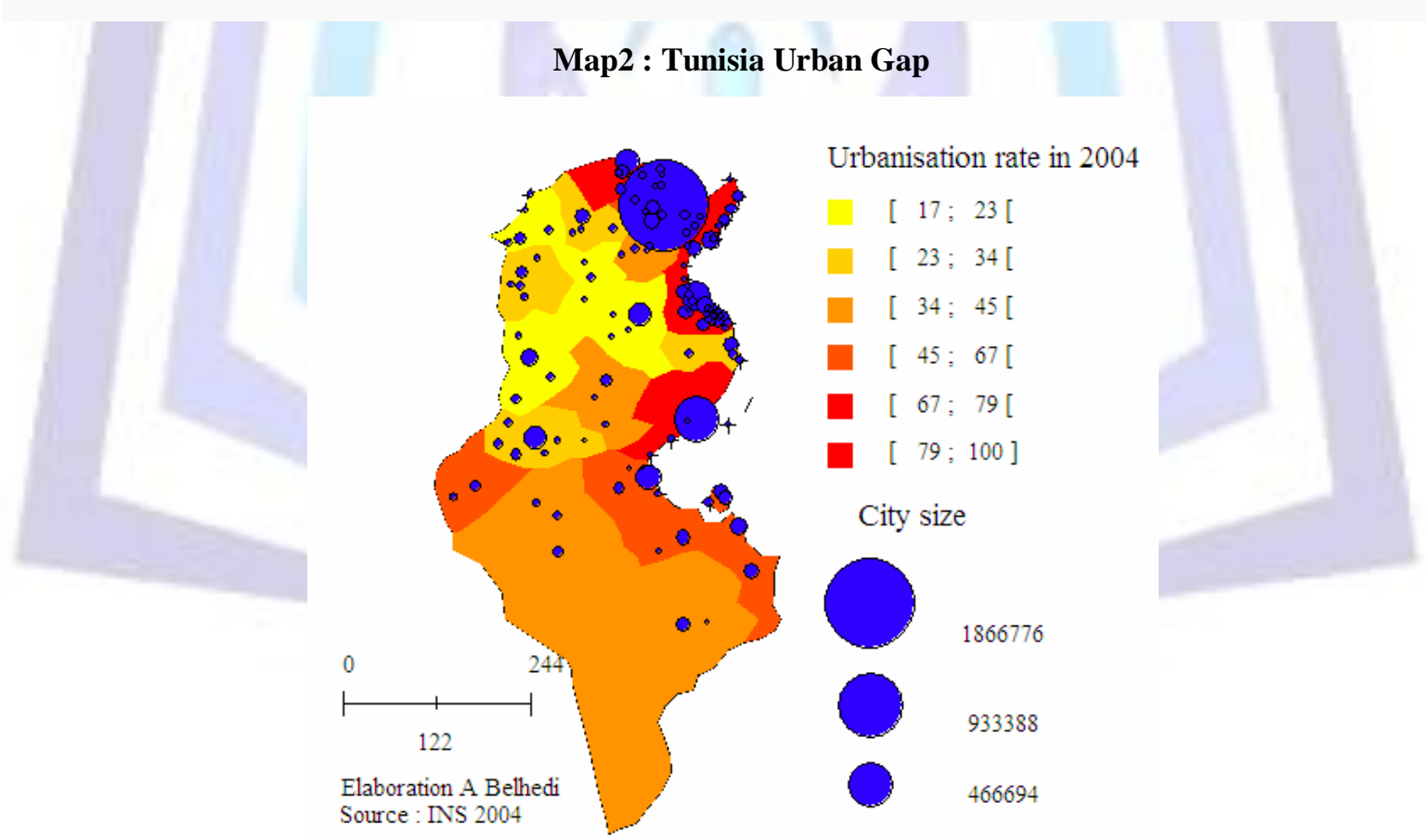

In their studies on inequalities in Tunisia, Mohamed Kriaa, Zouhour Karray and Slim Driss argued that inequalities between regions and delegations in Tunisia are correlated to neo liberal openness policy making. In fact, the location of foreign companies settled thanks to 1972 law was an incentive to foreign development investment FDI may benefit relatively to hintherlant disadvantaged areas. The authors, highlighted that « foreign companies may choose to settle in developped areas where exist accomodations and facilities. Then inequalities between delegations increased. » (Kriaa, Karray, $2011: 11$ ) 


\section{Map3 : Companies Representations' locations in Tunisia}
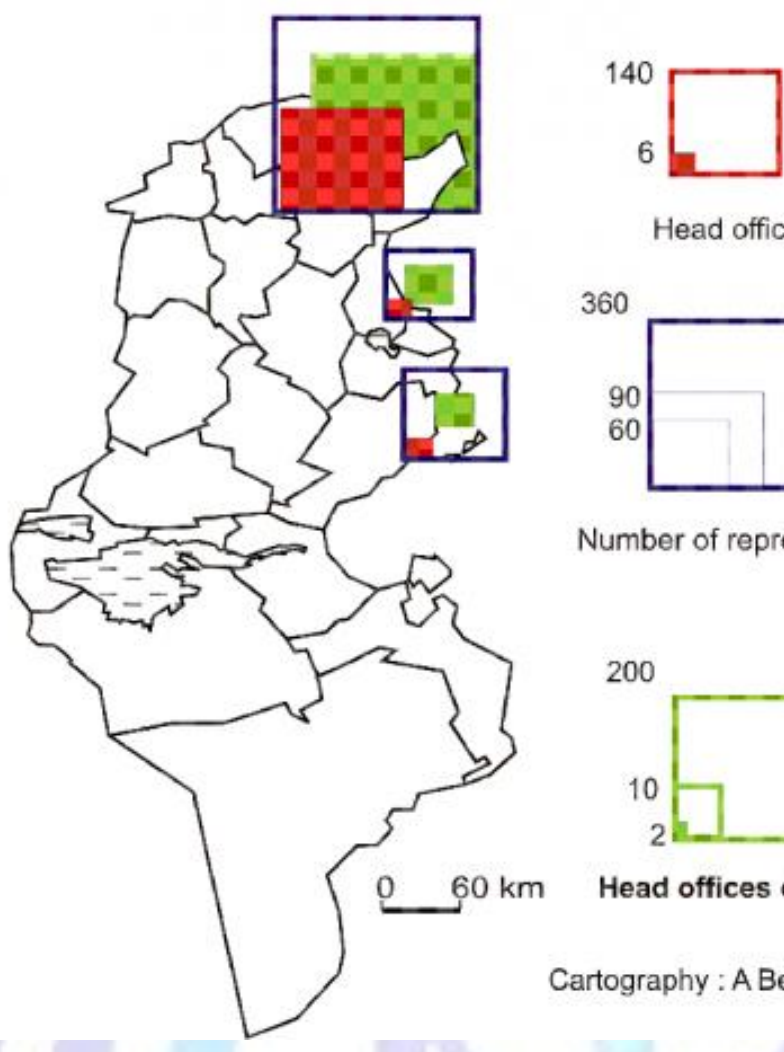

Head offices

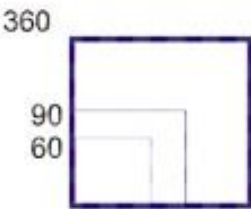

Number of representations commanded

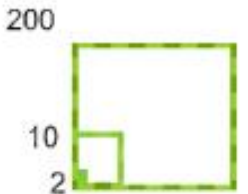

Head offices of companies with representations

Cartography : A Belhedi 2006

The costal aereas benefitted of development policies. More than sixty per cent of investments are concentrated on littoral areas, mainly Tunis and North East and South East. The new technolgies of information and communication, cosmetic, tourism and refined commerce (e.g.,export industries, textile) are located in the Eastern littoral areas.(Belhedi2004). During important forum held in Tunisia in September, 2014 many investors from worldwide attended the forum and are committed to invest in Tunisia (i.e., Economic city in Enfidha nearby Sousse, financial harbour in Tunis to name but a few). Would those project be achieved in short-run ? They are planned to be implemented within three years, after elections(2014) in Tunisia. Those mega project would garantee around 250.000 jobs opportunities. In fact, many resiliences exist which could hamper foreign investment in Tunisia(e.g. land planning documents, growing terrorism, governance).

In the same way, continuing to invest in the littoral would deepen more and more the territorial and social gaps between coastal areas and hinterland, and the urban syndrome would worsen furthermore. It seems that the same tendency consisting in doing city for profit persists instead of making « cities for people ». ((Marcuse, Peter, Mayer Margit et al, 2011)

\section{Map 4 : High School Diploma Success Rates}

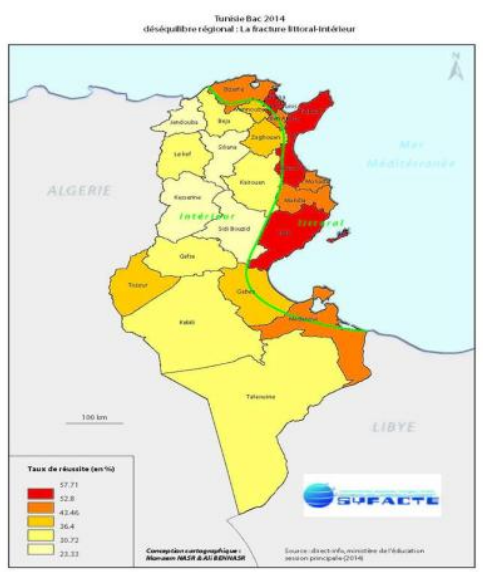


Sfax, the second city in Tunisia, considered alledgedly as the south capital, and to be in vain the regional metropolis for the southern neighborhood. Though, many of its inhabitants emigrated to the capital Tunis and elswhere in Tunisia and abroad. Many sfaxians are self-entreupreniers. They invest in : Agriculture in Sidi Bou Zid governorate, in industrial and tertiary projects in north eastern regions. The city of Sfax composed of Medina, Bab Bhar «European core », the Jnens, the garden city(Ben Nasr2013). The city development witness several economic, social, and environmental biases(e,g. floods, transportation network, lack of infrastructures) the planned megaproject Taparura(2001) would extend the new city towards its eastern waterfronts and add about five hundreds hectares to the urban area on the seafronts. Since after the technocratic interim government Mehdi Jomaa decision to begin deepwater port and mega economic projects in Enfidha in North East of Tunisia, civil Society associations in Sfax gathered in front of municipalty headquarter to claim the implementation of the planned megaproject Taparura7and urban development of Sfax. It is not, in our opinion a regionalism, but a competing between two main strategic cities (i.e., Sousse and Sfax) in the global urban development in the country, which is still in favor of north east coastal areas.

\section{Informal activities, and territorial hiatus :}

Since seventies, social movements were growing (January, 26, 1978) and in the eighties along with a culminate economic crisis (January, 3d, 1984) when the government decided to lift subsidies on foods; the president Bourguiba at the begining of the end of his reign resiliated the government decision in order to apaise the people outrage. The miner basin movements (January, 2008) against recruitment by clientilism, obedience to the regime was led by bottom trade unions in Sfax Gafsa Company and in the West region of the country Gafsa. In Summer of 2010s, in the border town Ben Guerdane, the informal traders and unemployed youth of the region opposed to the authorities which decided to close the Ras Jeder Gate. It is the main means of living of many families in the area.

\section{Map5 : Arms Trafficking Routes in Tunisia}
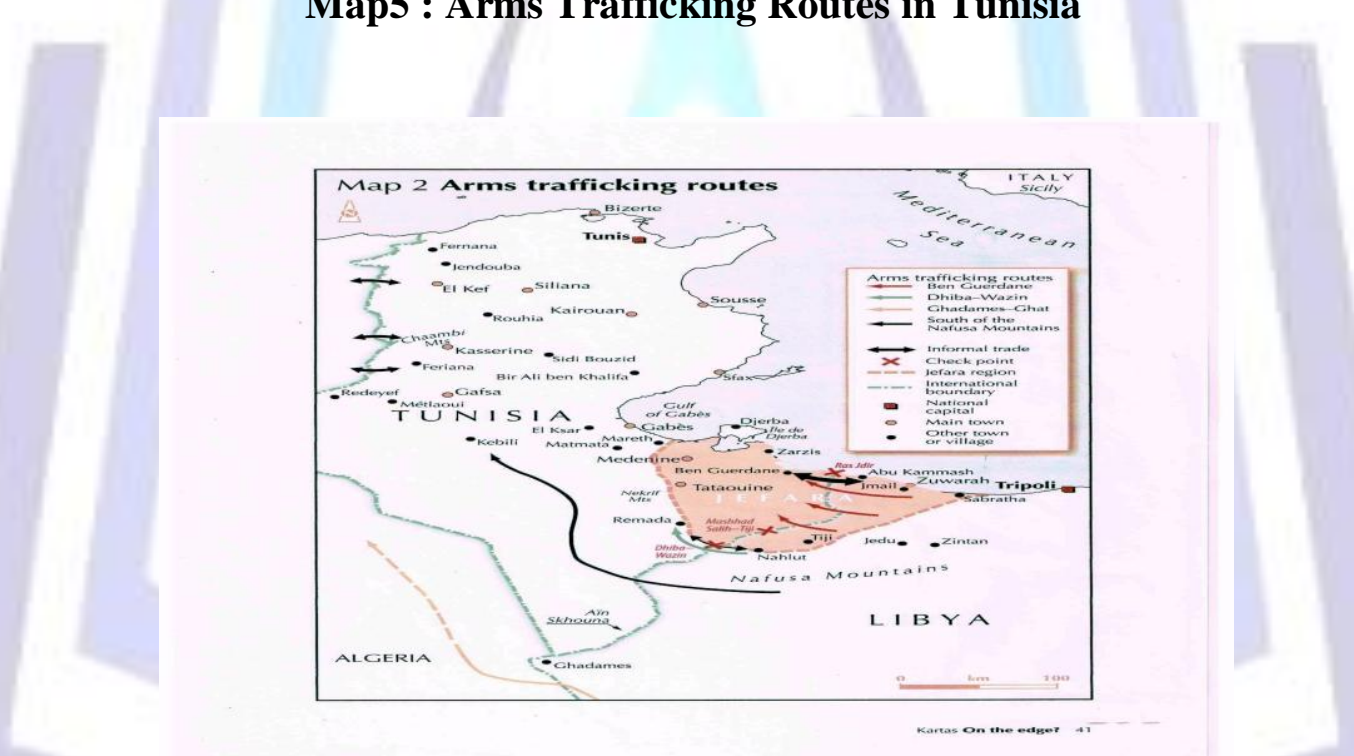

The urban vacuum or what we can call « space of chaos »(Balandier 1988) charactherizing South Eastern, south western, central western, and North western area is an area of poverty, social exclusion and marginalization due to previous development policies led by Nation-State. In the south East, Jeffara area(cf. map 5 below) is arid where rain fall doesn't exceed 200milimeters by year, pastoral activities(camels, livestock)is the most important livelihood in history, agriculture represents around 17.3 of useful agricultural land.(Boubakri and Nouri, 2009 :115). Many of the Jeffara inhabitants emigrate to north Tunisia(Tunis, mainly, to Libya or to Europe where they exert some activities traditionnally well known in the areaFtaïri (doughnuts maker), bakery, Hammas (dried fruits seller).

The former president Zine Al Abidine ben Ali made a deal with border tribes and smuggling barons, and turned a blind eye on informal exchanges between Libya and Tunisia.Most of borders' tribes cooperate with his regime and didn't allow any arm and drug trafficking. In their tours, informal commerce barons required that Ben Ali and Kaddafi relatives and families shouldn't interfere in their business. However, in 2010s, Ben Ali relatives influenced him to impose a tax on crossing border gate by informal traders in Ben Gardane. Therefore, this decision triggered uprising among local populations. Many clashes occured against authorities.

In fact, local populations living across borders, and even in many towns and villages,are occupied by informal commerce whith about 42 per cent. Few barons became the richest, other intermediairies gain their livelihood

\footnotetext{
${ }^{7}$ Taparura is a megaproject planned in 2001 across Sfax city waterfronts, but it is istill on stand-by due regime changes in Tunisia in the aftermath of the Revolution.
} 
through informal commerce with Libya, and Algeria. We can locate those informal activities in a broader worldwide economic network (e,g., US and China commerce deals). The economic competitions between super powers in the world. Wholesalers in Libya import goods from China, India, Turquy and stock them in wharehouses. Retailers from Ben Gardane and others buy those merchandises through money exchangers, cambists who provide Libyan currencies with interests.- Sometimes Banks make the operation. The benefits of this commerce are 50per cent or more when they are free custom taxes. There is often a connivance between traders and customs and border security agents to not pay customs fees. The driver of the trucks transporting imported goods earn a salary of between 300 to 1000 Tunisian Dinars by trip ;it depends on the quantity and values of the transported goods. The main border stations controls are: Jendouba and Kef governorates in the North West, Kasserine in the Center West, Bouchebka, Tozeur in the South West, Ras Jedir in Ben Gardane South East, Wasin, Mashhad Salih in Tataouine, South East of Tunisia.

\section{Map6 : Local Tribes South Eastern Tunisia}

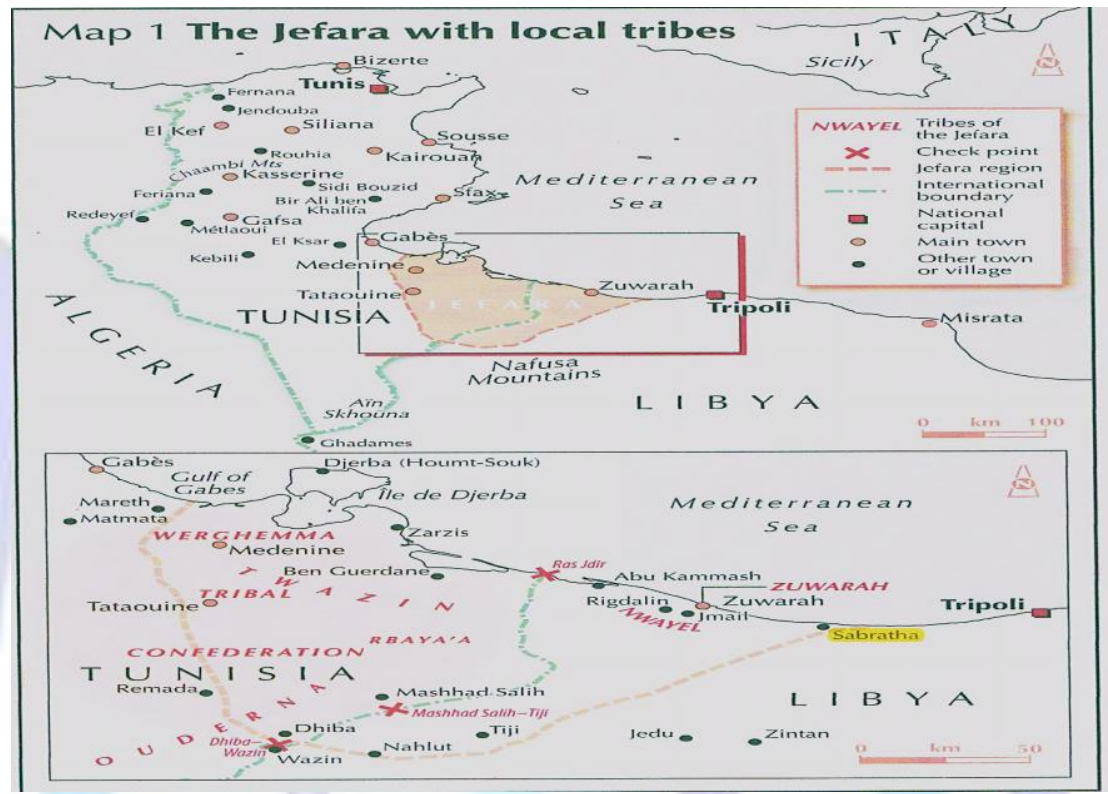

The tribal relationships are still at work in economy, society, and communication networks. The important tribes are(Werghemma in Medenine and Zarzis, Twazins in Medenine and Ben Guerdane, Ouderna, Tatatouine and Remada, Nwayel across Ben Guerdane onboth sides of Libya and Tunisia). There is an interconnexion in kinship, economic exchanges, and cultural ones. Informal commerce had grown on the Tunisian borders with Libya, and Algeria.

Moreover, some evidences prove that smugglers and arm traffickers are in close connection with terrorists(i.e., official statements of security authorities). Close connivances exist sometimes between security forces, customers and smugglers. Since the nation-state had weakened in the aftermath of December 17, 2010s and 14 January, 2011 uprising, corruption practices arose. Some commercial traders are in odds with some custom and police agents and engage in arm trafficking from Libya and Algeria to supply terrorist groups networks in Tunisia and maghrebian neighbor countries. The united nation report confirmed those practices as follows :

"On the one hand, evidence from across Latin America suggests that these groups are often at odds with police and engage in a variety ofactivities that contribute to a deterioration of the rule of law in major cities. Theymay involve themselves in broader organized criminal activities and, as a result of their local legitimacy, can easily develop ties with corrupt State officials. Such groups can become involved in acts of communal violence in regions of Asia and Africa. On the other hand, police, especially in Africa, have found themselves in situations where it may make tactical sense to develop ongoing relation ships with these groups » (UN Habitat, 2011)

In North western regions, informal activities are growing among local inoccupied population. In these areas, agriculture activities are the most important ones. Though, some problems of water costs, natural disasters (i.e., floods, wildfires)undermine development. Thereis a negative migratory balance between north eastern governorates(Le Kef, Jendouba, Beja, and Siliana). Youth unemployment is very high mainly among university graduates. 
Table2 : Youth Unemployment by Regions in Tunisia

\begin{tabular}{|l|l|l|l|l|l|}
\hline & $15-19$ years & $20-24$ years & $25-29$ years & $15-29$ years & $30-34$ years \\
\hline Tunis District & 52.8 & 52.2 & 31,9 & 36.7 & 18.5 \\
\hline North East & 40.5 & 36.7 & 29.0 & 33.7 & 19.6 \\
\hline North West & 50.0 & 43,8 & 37.2 & 41.5 & 19.6 \\
\hline Center East & 22.0 & 25.1 & 22,4 & 23,3 & 12.1 \\
\hline Center West & 61.7 & 63.2 & 52.4 & 57.9 & 31.8 \\
\hline South East & 48.0 & 53.1 & 45.8 & 48.6 & 26.1 \\
\hline South West & 60.2 & 60.5 & 53.8 & 56.5 & 24.8 \\
\hline General Total & 43.6 & 41.8 & 34.5 & 38.2 & 19.0 \\
\hline
\end{tabular}

Source:http://i0.wp.com/www.thetunistimes.com/wp-content/uploads/2014/05/table2.png

\section{EDUCATION ENROLMENT DISPARITIES:}

Women unemployment reaches about $25.6 \%$ against $14.6 \%$ rate for men. On the higher education level, the more graduated women are, the most exposed to unemployment $(43.5 \%)$ in comparison to men(20.9\%) in the same year 2012 . Rates vary by regions : south-west $(54.5 \%)$, south-east $(48.3 \%)$ and central-west $(45.9 \%)$ of Tunisia. The total number of unemployed universities graduates was around 174,900 people in 2012. Their unemployment rate increased from $18.7 \%$ in 2007 to $23.3 \%$ in 2010 and $33.2 \%$ in 2012 . « Masters graduates (with a master's degree or have successfully completed four years of university education) constitute $56.7 \%$ of total unemployed graduates in 2012. Their number has doubled in within five years from 46,100 in 2007 to 99200 in 2012. Official data reveal that school enrolment are higher for girls in secondary and higher education levels. Among 22 educational fields, 14 are hugely femal such as: social and human sciences, languages, Economy, Information, Law, agriculture, services. Girls are less represented in : ingenieuring diploma (29\%), architecture $(34,5 \%)$, veterinary medecine(35,9\%), physicisme sciences $(45,9 \%)$, informatics $(47,4 \%)$, mathematics (Gribaa et Depaoli, $2014: 4)$ But, women remain vulnerable to more unemployment, poverty, health, and economic risks. School enrolment and success rates vary through regions and delegations.

This soaring unemployment rate is an obvious indicator of the critical financial situation of the country. As we demonstrated in our recent reseach on territorial inequalities in Tunisia (Mahmoud 2014), Nation-State failed to ensure a fair urban planning. In fact, the deep gap between littoral areas and mainland persists. But note thand eventhough in littoral areas of Tunisia, social inequalities exist between haves and have-nots(Boughzala, 2014, Karray, 2011).

We have, also, to address this phenonomenon in its complexity. In fact, many economic and social interconnexions could exist between hinterland and homeland of the country. An aimed urban justice couldn't be to the detriment of an area than another. Could we assert in this way that an urban network of Tunisia joins in a networked society characterized by urban nodes within 'globalized world cities'(Sassen 2013). Those rates witness that higheris the cultural capital (Bourdieu 1969), easier is the social ascension. Though, high degree diploma are not any more a passsport for the upward social mobility as it was the case in sixties and seventies.In the Center West of Tunisia, the highest rates of unemployment are amongst the university graduates. (e.g., Ezzouhour ${ }^{8}$ quarter in Kasserine where many jobless youth are recruited by smugglers and terrorist groups). Those social anomies should be tackled as total phenomenon linked to the previuos development policies in Tunisia.

Since 1980s, regionalisation has been a mere framework for different development plans (Belhedi, 2012). Only, since the fifth development plan that state undertook the regional dividing of the country to six or seven regions. In 1980s, poor people represented about 52 per cent of tunisian population. By 2000 s, in urban areas, poverty rate (52\%) was higher than in rural ones. Only, in 2005, the situation had reversed and the urban poverty rates decreased drastically by 3 points (Sboui, $2012: 62$ )

The national schema of territory planning of 1985,1998 , and 2010 s did reproduce the classical checkerboard in order to fix each region population. The National Schema of Territory Planning (NSTP) of 1998 resumed that of the 1985 highlighting the East-West cleavage of utilitarian, metropolitanian development of the country. Amor Belhedi(geographer) argued in this issue: « We should, also, highlight that the three National Schemas of Territory Planning were designed in periods of economic crises $(1985,1997-98,2010$ s). The paradox is that planning targets only regulation but not sustainable urban planning. Some

8 See Table 2 
institutions were created such as : General Commissionership of Regional Development and proceeded to the creation of credit cards of Regional Development Plan, and afterwards Regional Plan of Integrated Development and the several Regional Development Plans along with The Office of Development of the North West(ODNW), and the Office of Development of the south (ODS) ; Office of Development of the Center West(ODCW). "(Belhedi 2012). The monoparty State led by Habib Bouguiba, and presidentialist regime of Zine al Abidine ben Ali adopted atop-down economic, urban development which begot the spatial inequalities.

\section{Spatial Injustices and democratic transition challenges :}

There is slight difference between justice and equity.In sustainable development, every citizen has the right to meet his needs for a better life. Justice is recognizing people fundamental human rights to livehood needs, recreation, education healthcare, civil and political rights to live free with dignity. Since those rights were violated under former regime, uprising had been growing in the West of Tunisia (e.g.,Gafsa, 2008 ; East, Ben Guerdane, 2010 ; Sidi Bou Zid, December 17, 2010s) where land use planning witnesses many spatial disparities.

National Schema of Town Planning 1996 bet more on more equipped spaces Tunis-North East in order to resist to international competing, and to globalization challenges. Consequently, the costal area developped and the interior land was left behind. These urban planning policies were inscribed within the Structural Adjustment Plan (1986) encouraging privatization and the withrawl of state from economic intervention after the end of welfarestate.

The lack of local resources in agriculture, in mining or energy made the following development policies relying on Libya, and essentially on French and European countries which are the privileged economic partners of Tunisia. Indeed, commercial exchanges with France are about 80 per cent. Moreover, United States is concerned by Tunisia given its location between North Africa and Middle East, and its neighborhood in South East with Libya where milicia control the country and the main petroleum site resourcesexist.

Unlikely, United States and Europ are still facing the acute fallout of the global financial depression due to the crash of main banks that overspread worldwide. When there is a close link between Arab, North African and other worlwide economy, the impact of the capitalist neo liberal crisis is obviously real on the local Tunisian economy.In the last few decades, regional planning action were focused on water irrigation system and agrarian areas. The Ttunisian economy slow down and the shrinking of the middle classes level of living is not necessarily entailed by the Revolution which is never to be only " explainable only by Mohamed Bouazizi self immolation ». (Belhkoja 2012).

Can we assert that economic development could be reached regardless of politics ? What does development mean ? Does development meangrowth ? The Human Development Index calculated by means of Gini index does never more confine HDI into economic growth. So far, we shall take into consideration other variables such as gender equality, school enrollment, healthcare, environment sustainability, governance, recreation, civil rights, transnational right to rights.

In post-revolutionary Tunisia is final drafting and approvment of the constitution enough to achieve the 17th December2010s and January 14th, 2011 revolution's objectives ? Civil society activists fuelled social movements all over the country and ended by a consensus about the constitution of technocratic government. After the successful parliamentary elections, a new elected government has to deal with many development problems(e.g.,inequality, poverty, social exclusion) mainly in the left behind areas.

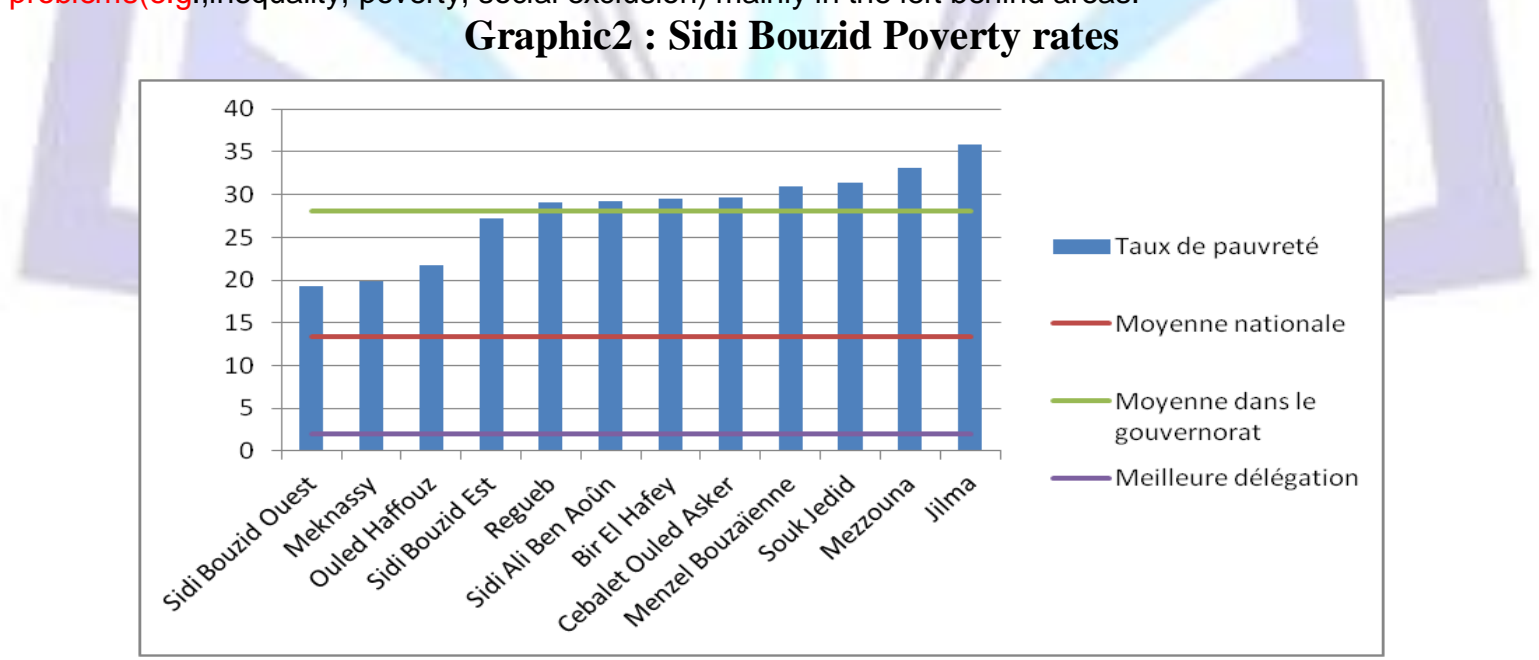

Source : Ministry of Development and Regional Planning of Tunisia, 2011

The Troïka9government stepped down under street civil society activism pressures, the new interim government led by a consensual Pime Minister deputy Mehdi Jomaa is trying to get the country out of the bottle neck within acute economic and social crisis context. The GDP shrinked remarkebly in the dawn of the revolution $(1.9 \%$ of

\footnotetext{
${ }^{9}$ Troika: the former ruling three main parties (Ennahdha: islamiste Party, CPR: Congress for the Republic, and ETTAKOTTEl: Union for Labor and Liberties: Socio Democratic party)
} 
GDP in 2011). Some more unexpected relative growth by $3.6 \%$ in 2012 . However this rate has slown down to $2.6 \%$ since phosphate and manufactures diminished their productivity and energy, and agriculture products sectors have decreased. Unemployment rates diminished slightly from 16.7 per cent in 2012 to $15.3 \%$ at the end of 2013. However, It is still above the pre revolution level of $13 \%$.

The main strategy of the technocratic interim government was to restore security, lift economic growth, and achieve the elections by the end of 2014. However, the growth rate wouldn't exceed 2.8 by the end of 2014 which means only 0.8 growth inasmuch, one point growth ensures, in principle, 15000 new additional job opportunities. Unemployment among young graduates, remains, nevertheless, at a particularly worrisome level (34\%, or one out of three), due to a widening gap between their abilities and the needs of businesses. Based on the results of the National Survey on Population and Employment ${ }^{10}$ for the fourth quarter 2013, the number of unemployed people stood at 609.9 thousand of the total active population, estimated at 3,978.6 thousan

\section{Graphic 3 : Kasserine governorate families in need}

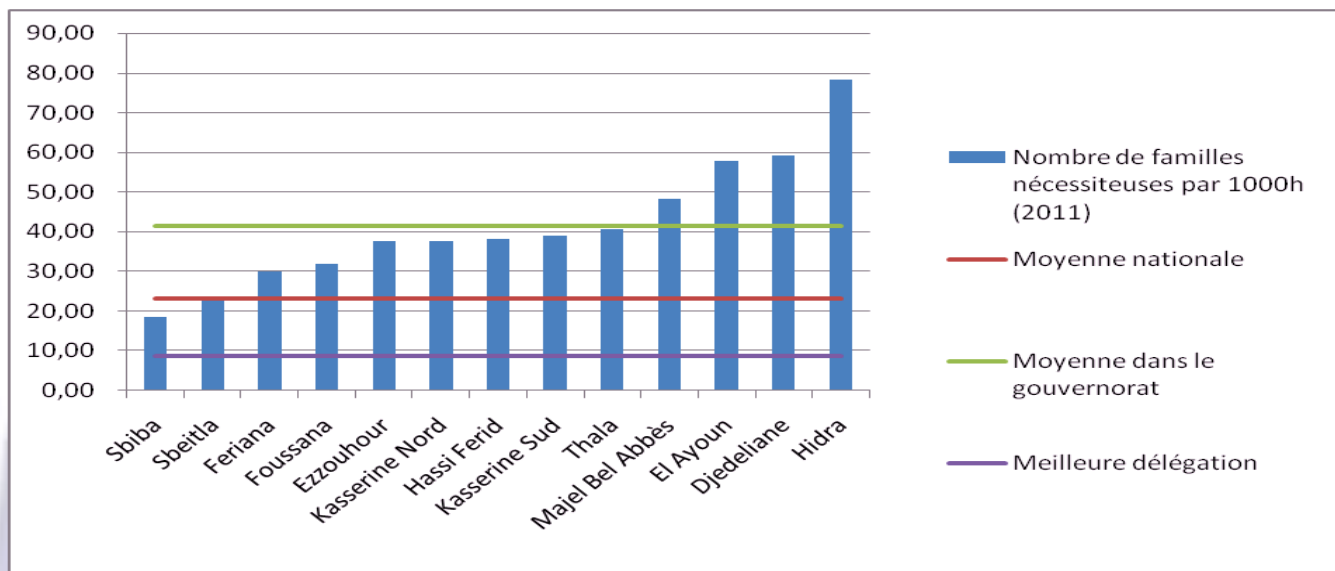

Source: Ministry of Regional Development and Planning of Tunisia, (2011)

The unemployment rate is higher for women21.9\% and $12.8 \%$ for men according the recent estimates in the third quarter of 2013.The number of unemployed graduates of higher education is estimated at 242.3 thousand in the fourth quarter of 2013 , which corresponds to an unemployment rate of $31.9 \%$, against $33.5 \%$ in the third quarter of 2013 , In February 2014 , after having culminated at $6.3 \%$ one year earlier. The new financial law has been approved after many controversies among representatives in the ANC11. "In early 2014, both reserves and the currency recovered somewhat, on account of increased confidence after, the resolution of the political crisis. »(World Bank, 2014)

The terrorists acts committed by Jihadists against : opposition political Leaders (e.g.,Lotfi Naqdh, Chokri Belaïd, Mohamed Brahmi), and Tunisian army and security agents entailed economic and political turmoils. Amira Kaddour and Zmami Mourad (economists) concluded that there is no positive correlation between economic growth and terrorist acts. However, the study results highlight the negative effect of political events and terrorists acts on stock market volatility. (Kaddour and Zmami, 2011)

As far as statistics in measurement of economic performance and social progressare concerned, Joseph Stiglitz pointed out :

«When there are large changes in inequality (more generally a change in income distribution) gross domestic product (GDP) or any other aggregate computed per capita may not provide an accurate assessment of the situation in which most people find themselves. If inequality increases enough relative to the increase in average per capital GDP, most people can be worse off even though average income is increasing » (Stiglitz, 2009: 8).

Notwithstanding the new economic measures, some geostrategic and anthropolical factors played a key role in the economic worsening stuation. Tunisia cultural structures remain at works in resilience to Nation-State hegemony. Communities, kinship mainly in hinterland, are still important whenever, previous econonomic and social planning plolicies didn't succeed to achieve nor local development, nor fix people to their lands. Many of young people find themselves constrained to emigrate to Coastal cities or abroad (i.e., Libya, Europe). The emigration remittances and formal commerce retuns constitute the main people incomes in those areas.

\section{CONCLUSION REMARKS:}

\footnotetext{
${ }^{10}$ National Institute of Statistics, Tunisia 2013

1111ANC: National Constituent Assembley elected in October, 23, 2011 to draft a new constitution
} 
Sustainable urban development in post-revolutionary Tunisia is facing myriad of challenges. Spatial and territorial inequalities could hamper democratic transition process. Many social, economic, and cultural aleas such as terrorism, informal activities, ecological syndrome constitute resiliences to sustainable urban governance implementation. Previous urban development policies undertook since independency entailed a deep gap between coastal regions and hinterland. As a subsystem within a global economic system, Tunisian economy and society developped amongst a liberal and new liberal economics, and bisectorial economy of formal and informal sectors is not conceivable in a mere dual approach. Both sectors blur and interfere within a networked world economy that transcends national edges to interconnect with global urban nodes(i.e.,New York, Tokyo, and London) and megapolises in Europe, America, Middle East, and China).

The top down policy makings followed by Tunisian State since indepedency deepened instead of reducing inequalities, they entailed economic, urban gaps and spatial inequalities

In order to mitigate those spatial and social disparities, and injustices, Tunisian State had put in place some urban planning institution framework that benefitted-economic world competitiveness obliged- more to littoral areas. The decreed parcelling out documents(e.g., Urbanism Code, Urban Planning Plans and Schemas of Urban Planning Master Plans) were conceived and achieved through top-down policy makings. Poverty and social exclusion were so acute in the central areas of th country (i.e.,Sidi Bou Zid, and Kasserine) that uprising had grown since 2008 and begot the December, 17, 2010, and january, 14, 2011revolution. Eventhough, the quartet and civil society succeeded to draft a new democratic constitution and fair democratic election, social and territorial inequalities persist between coastal and interior areas and between towns, rural areas, and between The better-off and the less well-off. Middle classes downsized to the lowest level of their living standing. Hence, those urban and social biases could hamper democratic process. The growing smuggling traffiks linked to the rise of terrorist acts targetting new nation-state are serious challenges against democratic process and economic recovery in Tunisia. New elected rulers have to achieve people expectations by ensuring security, and implementing a new sustainable urban planning in accordance with Tunisia revolution objectives (i.e, freedom, dignity and justice).

Energy sectors matter too much in econmic development of Tunisia. The country lacks energy resources, and has many renewable energy opportunities. However, those resources exploitation depend on good governance in this very sensible sector depending on national and supra national stakeholders that are competing in this issue. Energy intensity exploitation and seeking for new renewable ones are in the core of a sustainable social and territorial development. This development strategy requires that social and urban actors rely on local democracy strategies based on their social and cultural contexts ;a bottom up policy making shouldn't deny the top down state role in public spendings and fair taxations policies. The new ruling majority government of the main civic and modernist party Nidaa Tounes12has to rule the country, not alone, and according a multilevel governance for a sustainable urban planning with fairness, accountability and justice.

\section{References}

1. Abid, Mehdi et al. 2012. Energy Consumption-Economic Growth Nexus: Does the Level of Aggregation Matter? In : International Journal of Energy Economics and Policy Vol. 2, No. 2, 2012, pp. 55-62 ISSN: 2146-4553

www.econjournals.com retrieved on Wednesday, 9, July, 2014 at $9: 42$

2. Ali Bennasr, Taoufik Megdiche, and Eric Verdeil. 2013. Sfax, laboratoire de développement durable enTunisie ? ENVIRONNEMENT URBAIN, 2013, 7, pp.83-98.

http://halshs.archives-ouvertes.fr/halshs-00857582

Submitted on 3 Sep 2013

3. Amin, Samir.2003. Obsolescent Capitalism : contemporary Politics and Global Disorder, New York : Zed Books, 190 pages

http://books.google.fr/books?id=1ibCSFn_CqkC\&printsec=frontcover\&hl=fr\#v=onepage \&q\&f=false retrieved on Thursday, October 23, 2014 at $8: 14$

4. Amira Kaddour, Mourad Zmami. 2011. How Does Financial Sector Reacts After Special Events? An Event Study Analysis of Tunisia after the Revolution of 2011.

http://jssronline.com/ojs/index.php/jssr/article/view/60 retrieved on Wednesday, 23 July 2014 at 23 :35

5. Balandier, Georges. 1988. Le Désordre, éloge du Mouvement,Pari : Fayard, 252 pages

6. Belhédi, Amor. 2005. Différenciation et Recomposition de l'Espace Urbain en Tunisie Cahiers du GREMAMO, $n^{\circ} 18$ Laboratoire SEDET-CNRS Denis Diderot, Université Paris VII (France), 266p L'Harmattan, Paris, 2005

http://archive.today/OOiQb retrieved on Sunday, May, 31, 2014 at $22: 30$

\footnotetext{
${ }^{12}$ Nidaa Tounes is the first winning party in the Tunisian parlementary elections held in Tunisia on Sunday, October 26, 2014. This party was formed after the first National Constituent Assembly (October, 23, 2011. It is composed of four main political pillars : Former Ruling Party Democratic Constitutional RallyRCD, Independent, center Leftists, and Syndicalists
} 
7. Belhedi, Amor.2004. The Tunisian Urban System. Demographic and fonctionnal hierarchical analysis based on the Rank-Size Rule

http://cybergeo.revues.org/3877 retrieved on Sunday, October, 12, 2014 at 9 :02

8. Belkhoja, Abdelaziz \& Cheikhrouhou Tarak. 2013. 14 Janvier, L'Enquête, Tunis: APOLLONIA ÉDITIONS, 191 pages

9. Bolzon, Hugo. 2012.Les enjeux du développement et de la gestion du gaz naturel dans les villes tunisiennes : cas de l'agglomération de Sfax Mémoire réalisé par Hugo Bolzon, et dirigé par Eric Verdeil Stage de recherche dans le cadre du Master 1 Urbanisme et Aménagement, Institut d'Urbanisme de Lyon, Université Lumière Lyon 2 dumas-00745821

10. Boughzala, Mongi and Tlili Mohamed hamdi. 2014. Promoting inclusive growth in Arab countries : rural and regional development and inequality in Tunisia

http://www.brookings.edu/ /media/research/files/papers/2014/02/promoting\%20growth\%20arab\%20countrie s/arab\%20econpaper5boughzala\%20v3.pdf retrieved on Friday,17 July 2014 at $17: 07$

11. Ben Hammamia, Amira. 2014. Analysis of the Decomposition of Energy Intensity in Tunisia IN : International Journal of Energy Economics and PolicyVol. 4, No. 3, 2014, pp.420-426 ISSN: 2146-4553

www.econjournals.com

http://www.econjournals.com/index.php/ijeep/article/view/829/478 retrieved on Friday, October, 24, 2014 at $5: 42$

12. Bourdieu, Pierre. 1990. The Logic of Practice, California: Stanford University Press, 333 pages

13. Braudel, Fernand.1992. Civilization and Capitalism, 15th-18th Century: The structure of everyday life, Berkely and Los Angeles : University of California Press, 623 pages

14. Castells, Manuel.2012. Network of outrage and Hope, social movements in the Internet age, Cambridge : Plity Press, 298 pages

15. Corfee- Morlot, Jan Lamia Kamal Chaoui ; Michael G. donovan, lan Cochran ; Alexis Robert and PierreJonathan ; Teasdale (2009), OECD publishing, OECD

16. Dlala, Habib et al. 2010. MondialisationetChangementUrbain, Manouba: University Press Center, 309

17. Fromm Erich. 1968. The Revolution of Hope,1rst edition, New York : Harper \&Row,

18. Gonzelman, Robert. (2008). Towards a new concept of multi-level governance?

Remarks by Dr. Thomas Conzelmann, University of Maastricht MLG Atelier, 10 September

(Revised version: 25 September 2008)

http://cor.europa.eu/en/activities/governance/documents/Conzelmann.pdf retrieved on Wednesday, August, 30, 2014 at $6: 46$

19. Hassen, Boubakri et Habiba Nouri. (2009). Migrations, transformations sociales et recompositions des territoires dans la Jeffara (Sud-Est de la Tunisie) IN : Développement rural, Environnement et Enjeux territoriaux Regards croisés Oriental marocain et Sud-Est, Tunis : Cérès Editions tunisien

http://horizon.documentation.ird.fr/exl-doc/pleins_textes/divers13-07/010050194.pdf accessed

on Friday, March, 7th, 2014at $9: 53$

20. Hiroyuko, Hito. 2013. Renewable Energy in Tunisia, Working Paper

http://policyleadershipinstitute.org/documents/RENEWABLE\%20ENERGY\%20IN\%20TUNISIA\%20-

\%20IPLI\%20Working\%20Paper\%20-\%20Hiroyuki\%20lto.pdf retrieved on Wednesday, July 9, 2014 at $7: 42$

21. Hayder, Adnan. Belhedi, Amor.(2013). Localisation industrielle et enjeux urbains en Tunisie http://tel.archives-ouvertes.fr/docs/00/95/88/30/PDF/2013_soussi_arch.pdf retrieved on Sunday, August, 18,2014 at $10: 02$

22. Henrik Enderlein, Sonja Walti, Michael Zurn. (2010) Hand Book on Multi-level Governance, Massachussets : Edward Elgar Publishing, 504 pages

http://books.google.fr/books?id=YlmoCs207UAC\&printsec=frontcover\&hl=fr\#v=onepage\&q\&f=false

retrieved on Thursday, October, 29,2014 at :7:59

23. Karray et al. 2011. multidimensional inequalities in Tunisia

http://www.erf.org.eg/CMS/uploads/pdf/Driss\%20Kriaa\%20\&\%20Karray.pdf retrieved on Sunday, May, 31,2014 at $21: 47$

24. Kartas, Moncef. 2013. On the Edges ? Trafficking and Insecurity at the Tunisian-Libyan Borders http://www.smallarmssurvey.org/fileadmin/docs/F-Working-papers/SAS-WP17-Tunisia-On-the-Edge.pdf accessed on Thursday, 6, 2014 at $20: 45$

25. Mahmoud, Abdesselem.2014. Territorial and social Inequalities in Tunisia, which sustainable urban governance In : Review of Research, Vol. 3 Issue.5, February, 2014 ISSN:-2249-894X Available online at www.ror.isrj.net

26. Marcuse, Herbert.1964. One-Dimensional Man:Studies in the Ideology of Advanced Industrial Society http://www.marxists.org/reference/archive/marcuse/works/one-dimensional-man/one-dimensionalman.pdf retrieved on Sunday, 12 October, 2014 at $8: 24$ 
27. Ministère du Développement Régional et du Plan, Indicateurs de développement Régional Sidi Bouzid http://www.mdci.gov.tn/tn/Gov/indica/sidi\%20bouzid.pdf retrieved on Wednsday, 12, August, 2012 at $11: 18$

28. Moalla, Mansour. 2011. De l'Indépendance à la Révolution système politique et developpement économique en Tunisie, Tunis : Sud Editions, 643 pages

29. Observatoire Tunisien de l'Economie. 2013. In : International Journal of Energy Economics and Policy Vol. 4, No. 3, 2014, pp.420-426 ISSN: 2146-4553

www.econjournals.com

http://www.investir-en-tunisie.net/pdf/Mensonges_gaz_de_Schiste_OTE_2013.pdf retrieved

on

Saturday, Septeber 13, 2014 at $13: 04$

30. Boutheina Gribaa et Madame Giorgia Depaoli.2014. Profil genre de la Tunisie. Document rédigé dans le cadre de la mission d'identification d'un programme de promotion de l'égalité homme-femme en Tunisie financé par L'union Européenne-Version Courte.

http://eeas.europa.eu/delegations/tunisia/documents/page_content/profil_genre_tunisie2014_courte_fr.p df Retrieved on Saturday, October, 25,2014 at : $19: 57$

31. Saskia, Sassen.2013. The Global Cities : New york, London, Tokyo,New Jersey : Princeton University Press, 480 pages

32. Sboui, Fawzi. 2012. Effect of growth and inequality on poverty in Tunisia IN : Région et Développement, No 35, 2012

http://region-developpement.univ-tln.fr/fr/pdf/R35/4_SBOUl-1.pdf retrieved on Friday, October, 2014 at $6: 23$

33. Soja, W. Edward.2008. The city and spatial justice, Paper prepared for presentation at the conference Spatial Justice, Nanterre, Paris, March 12-14, 2008

http://www.jssj.org/wp-content/uploads/2012/12/JSSJ1-1en4.pdf retrieved on Friday, October 24, 2014 at $22: 52$

34. Harvey, David. 2012. Rebel Cities: From the Right to the City to the Urban Revolution, New York- Verso Books, 216 pages

http://books.google.tn/books?id=s4s5f7NnaZAC\&printsec=frontcover\&dq=the+city+urban\&hl=fr\&sa=X\& ei=C61rU90UO6Gs0QWSgIGQDQ\&ved=0CHQQuwUwCQ\#v=onepage \&q=the\%20 city\%20urban\&f=fal se retrieved on Thursday, 8, May, 2014 at $17: 40$

35. Stiglitz, Joseph.2012. The Price of Inequality, New York : Allen Lane an imprint of Penguin Books, 414 pages.

36. Stiglitz,J. et al. 2009. Report by the Commission on the Measurement of Economic Performance and Social Progress www.stiglitz-sen-fitoussi.fr retrieved on Tuesday, June, 27, at $16: 13$

37. Trabelsi, Salwa. 2013. Regional Inequalityof Education in Tunisia: an evaluation by gini index http://region-developpement.univ-tln.fr/fr/pdf/R37/5_Trabelsi.pdf, retrieved on Saturday, July 52014 at $00: 30$

38. United Nations, African Union, African Development Bank, Economic and Social Council Economic Commission for Africa.2013.Draft Report on Sustainable Development Goals for North Africa

39. UN-Habitat.2012-2013.The State of World cities : prosperity of cities http://mirror.unhabitat.org/pmss/listltemDetails.aspx?publicationID=3387 retrieved on Sunday, 6, July 2014 at $7: 46$

40. Walerstein, Immanual. 2012. Special Symposium on the modern world system, IN : Contemporary

Sociology: A Journal of Reviews-2012-Wallerstein-6-9 American Sociological Association 2012 http://fr.scribd.com/doc/217937288/Contemporary-Sociology-A-Journal-of-Reviews-2012-Wallerstein-6-9 accessed on Sunday, April, 20, 2014 at $6: 42$

47. Worldbank. 2014. Tunisia Overview

http://www.worldbank.org/en/country/tunisia/overview retrieved on Tuesday, 8, July, 2014 at : $23: 2$

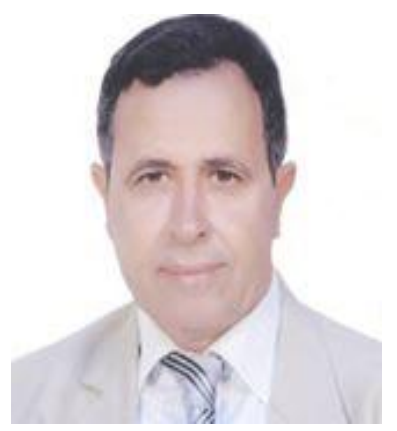

\section{Dr. Abdesselem MAHMOUD}

- Graduated from René Descartes University, Paris5, Sorbonne-France

- Associate Professorof Urban Sociology at National School of Architecture and Town Planning, Tunis.

- Town Planning Head of Department and Research Unit's on Land Uses and urban Designs at Carthage University, Tunisia

- Published books in French and English in Tunisia and papers on several topics: Urban studies, Social Exclusions, Social movements, Public Sphere... in local and International Journals and Reviews 